\title{
Dalmatians AND SlaVs IN VENiCE In THE LATE MidDle AgeS: \\ BETWEEN INTEGRATION AND ASSIMILATION \\ Ermanno Orlando
}

\section{Introduction: the demographic data}

At the end of the Middle Ages, Venice counted a population of around 120,000 inhabitants. More than a third were foreign, both of former or more recent immigration. In particular, the city included substantial communities of Dalmatians and Slavs, Germans, Albanians, Greeks, Armenians, Jews, Turkish Muslims and slaves. At the end of the Fifteenth century, the estimates drawn up show that there were around 4,000 Germans permanently resident in the city and an equal number of Albanians; 5,000 Greeks; and well over 5,000 Slavs-Dalmatians. To these, can be added the thousands of Jews registered at the beginning of the Sixteenth century and the thousands of immigrants from the nearby mainland or other parts of the Italian peninsula, especially Lombardy, Florence and Lucca, and the numerous contingents of slaves and servants serving in Venetian houses, probably totalling more than 40,000 people ${ }^{1}$.

\footnotetext{
${ }^{*}$ The essay put forward here partially picks up again, only about the Slavic-Dalmatian community settled in Venice, reflections and insights more extensively expressed in Orlando, Migrazioni mediterranee. Migranti, minoranze e matrimoni a Venezia nel basso medioevo (Bologna: Il Mulino, 2014). The research was based not only on the more traditional legislative and deliberative sources from the Venetian commune, but also on the wide range of judicial sources, both of a criminal and civil nature, produced by local lay and ecclesiastical tribunals: writings in recent years increasingly appreciated and used by scholars, who have also grasped their potential for themes such as migratory movements and the study of minorities. In particular, in the examination of one of the key players of integration into the lagoon society, that of mixed marriage, I have made a widespread use of matrimonial causes debated in the Patriarchal Court of Venice and of the documentation related to the ecclesiastical management of matrimonial litigations.

${ }^{1}$ For some data on the population of Venice in the late Middle Ages see: Julius Karl Beloch, "La popolazione di Venezia nei secoli XVI e XVII," Nuovo Archivio Veneto n.s., II, no. 3-I (1902): 5-14; Giorgio Fedalto, "Le minoranze straniere a Venezia tra politica e legislazione," in Venezia centro di mediazione fra Oriente $e$ Occidente (secoli XV-XVI). Aspetti e problemi, Atti del II convegno internazionale di storia della civiltà veneziana, Venezia 3-6 ottobre 1973, I, ed. Hans-Georg Beck, Manousos Manoussacas, and Agostino Pertusi (Firenze: Olschki, 1977), 146-149; Reinhold C. Mueller, "Peste e demografia. Medioevo e Rinascimento," in Venezia e la peste. 1348/1797 (Venezia: Comune di Venezia, Assessorato alla cultura e belle arti, 1979), 93-94; Brunehilde Imhaus, Le minoranze orientali a Venezia. 1300-1510 (Roma: Il Veltro, 1997), 37-39, 48-49; Andrea Zannini, Venezia città aperta. Gli stranieri e la Serenissima, XIV-XVIII sec. (Venezia: Marcianum press, 2009), 38-40; Benjamin Ravid, "Venice and its minorities," in A Companion to Venetian History, 1400-1797, ed. Eric R. Dursteler (Leiden, Boston: Brill, 2013), 454-456; Orlando, Migrazioni mediterranee, 45-46. On the German population in the city, see now in particular Philippe Braunstein, Les Allemands a Venise, 1380-1520 (Rome:
} 
The Schiavoni from Dalmatia, Istria and other Slavic countries were, therefore, one of the most significant foreign contingents in the city, mainly as a result of a continuous migratory flow of men and women fleeing from troubled and unstable regions, but very close to the Venetian lagoons. This flow of immigrants saw growth peaks at specific periods of time: the Black Death of 1348 and the wars that had affected the northern Adriatic in the second half of the Fourteenth century, when the increase of the migratory movement was favored by the policies of repopulation adopted at that juncture by Venice; the re-conquest of Venetian Dalmatia during the years 1409 to 1420 (after it had been lost in 1358 and incorporated into the kingdom of Hungary); lastly, the political upheavals in the Balkans caused by the Turkish conquests in the second half of the Fifteenth century. It was precisely in that period that the intensity of this migration had recorded its peak, as a result not only of the ongoing invasion, but also the weaknesses of an economy that had in those years revealed a certain fragility. The recruitment pool of Schiavoni covered a vast area, extending from Venetian Istria as far as the Dalmatian coast (down to Dubrovnik and Kotor) and the Balkan hinterland; obviously, the primary place for departures was from the coastal cities, though it is worth remembering that, as this was mostly immigration in stages, the seaside towns often represented the last stop off point along these routes that originated in the hinterland, and sometimes not even from areas close by. Up until 1450, first place was held by Dubrovnik (Ragusa), followed by Zadar and Split, then from Trogir, Šibenik and Kotor (only a few immigrants came from other cities, such as Krk, Nin or Pag); on the other hand, from that date onwards, the migratory streams were mainly from Kotor and Zadar, followed on by those from Šibenik, Split and Dubrovnik, and further afield, from Hvar, Senj, Budva and $\mathrm{Pag}^{2}$.

Economy, Labor and Migration Policies

Ecole française de Rome, 2016). On the numerous contingent of slaves and domestic servants see: Jacques Heers, Esclaves et domestiques au Moyen Âge dans le monde méditerranéen (Paris: Fayard, 1981), 144-158; Imhaus, Le minoranze orientali a Venezia, 156-160, 175; Dennis Romano, Housecraft and Statecraft. Domestic Service in Renaissance Venice, 1400-1600 (Baltimore, London: The Johns Hopkins University Press, 1996), 77 108, 122-129; Sally McKee, "Domestic Slavery in Renaissance Italy," Slavery \& Abolition 29, no. 3 (September 2008): 320-321; Zannini, Venezia città aperta, 40-41, 51; Orlando, Migrazioni mediterranee, 116-117.

${ }^{2}$ Ferdo Gestrin, “Migracije iz Dalmacije v Italijo v 15 in 16 stoletin,” Zgodovinski caposi 30 (1976): 269-276; Imhaus, Le minoranze orientali a Venezia, 39-42, 53-56; Bernard Doumerc, "L'immigration dalmate à Venise à la fin du Moyen-Age," in Le migrazioni in Europa. Secc. XIII-XVIII, Atti della "Venticinquesima Settimana di Studi", Istituto Internazionale di Storia economica "F. Datini", Prato, ed. Simonetta Cavaciocchi (Firenze: Le Monnier, 1994), 327; Lovorka Čoralić, U gradu Svetog Marka. Povijest hrvatske zajednice u Mlecima (Zagreb: Golden marketing, 2001), 81-100; Egidio Ivetic, "I Croati a Venezia. Alcuni studi recenti," Studi veneziani 46 (2003), 17, 28; Zannini, Venezia città aperta, pp. 62-63; Orlando, Migrazioni mediterranee, 79-81. 
Like many other great Mediterranean cities, the relationship between Venice and its immigrants had always been an obligatory and binding relation. Without a constant supply of new immigrants, the city would never have been able to bridge the gap in its demographic deficit and the constantly negative balance between its birth and mortality rate (typical of any city of the old regime). As a result, the migrant soon became a constituent element of the city and its society and a fundamental part of its economic and social life. The city's willingness to open up and welcome migrants and facilitate their entry was, therefore, based on a functional and very pragmatic view of immigration: the well-being and prosperity of the community could not have been achieved without foreign complicity. Immigration was structurally connected to society's needs; the city expressed an unbroken demand for both skilled and low-skilled imported labour, especially adaptable and flexible workers who could be used in the harshest and most strenuous production activities (and lower paid), such as shipbuilding, the sea industry or the textile industry. Work was, in fact, the main attraction engine for these migration flows to the city and also the most immediate route towards integration for newcomers into the host society ${ }^{3}$.

Politics had realised how indispensable the migrant was and modelled its choice around this, with particular regard to the needs of the economy. It had bargained to attract as many people as possible to the lagoon, often competing with other cities, sometimes resorting to active means of recruitment, in order to outweigh demographic deficits and meet the demands of the local production system, more often than not resorting to generically favorable attitudes, aimed at indulging migratory flows and encouraging people's mobility (making the most of the propaganda, founded on the myth of Venice being a hospitable, open and welcoming city). It is difficult to speak of real migratory policies at that particular period of time; indeed, they paid for a limited capacity for managing and controlling migratory flows, in Venice as elsewhere, often resulting in a sum of contingent and disconnected measures, if not confused and contradictory, dictated more by the result of an emergency or by circumstances rather than an organised and organic capacity to intervene $e^{4}$.

The structural characteristics of the Venetian market meant that the demand for immigrant labour was naturally concentrated in particular areas, such as the sea industry, services, goods handling and textile crafts, in other words, areas of employment with the toughest working conditions, the lowest paid salaries and the highest level of uncertainty, and for these reasons viewed with disdain and possibly avoided by the locals. The job market revolved around these more humble and hard

\footnotetext{
${ }^{3}$ Imhaus, Le minoranze orientali a Venezia, 252, 414-417; Zannini, Venezia città aperta, 76-77; Ravid, Venice and its minorities, 449-450; Orlando, Migrazioni mediterranee, 14-15, 35-38.

${ }^{4}$ Fedalto, "Le minoranze straniere a Venezia," 147-150, 161-162; Doumerc, "L'immigration dalmate à Venise," 328; Alain Ducellier, "Albanais dans les Balkans et en Italie à la fin du Moyen Age: courants migratoires et connivences socio-culturelles," in Le migrazioni in Europa, 255; Imhaus, Le minoranze orientali a Venezia, 252253; Reinhold C. Mueller, Immigrazione e cittadinanza nella Venezia medievale (Roma: Viella, 2010), 18, 24-
} 27, 103-104, 143-148; Orlando, Migrazioni mediterranee, 39-47. 
sectors of the employment world, id est jobs characterized by low qualification requirements and few guarantees as well as poor social appeal, ending up being filled mainly with foreign workers who, for obvious reasons, were more malleable and flexible than locals. Due to these mechanisms, some activities had had a fairly marked ethnic connotation; not surprisingly, research conducted so far has highlighted an undeniable gravitation of foreigners from the Balkan coastal regions towards employment in the sea industries, with peaks of $40 \%$, followed by the artisan sector $(16 \%)$ and trade services $(13 \%)^{5}$.

Another sector which recorded a substantial and persistent presence of Balkan migrants had been the service sector and home care (low-paid jobs, carried out under conditions of semienslavement with very few guaranteed rights). The demand for household staff had, in fact, always been very high in the city, providing immigrants not only with a minimum wage but also a stable dwelling, daily meals and the comfort of clothes and other basic necessities. Such generic workers, with no specific qualifications, were employed in the most varied of tasks; women were particularly involved in looking after homes and taking care of the elderly and children in private dwellings or working as assistants in hospitals and local leper institutes. Such work was often transitory, just long enough for the girls to put aside a sufficient dowry to contract a good marriage and for young men to find more acceptable and satisfying job opportunities ${ }^{6}$.

Indeed, to meet the continuous demand for domestic servants in urban homes, throughout the Middle Ages Venice had known a flourishing market, though partially illegal, of anime, id est children and teenagers generally baptized who were recruited more or less by force along the Balkan coast mainly Albanians, but also Schiavoni and Greeks - and who were taken to Venice under semi-slave-

\footnotetext{
5 Alain Ducellier, "Les Albanais à Venise aux $\mathrm{XIV}^{\mathrm{e}}$ et $\mathrm{XV}^{\mathrm{e}}$ siècles," Centre de recherches d'histoire et civilisation byzantines. Travaux et mémoires 2 (1967), 408-413; Imhaus, Le minoranze orientali a Venezia, 8597, 148-155, 184-187, 219-226; Alain Ducellier et al., Les chemins de l'exile. Bouleversements de l'Est Européen et migration vers l'Ouest à la fin du Moyen Âge (Paris: A. Colin, 1992), 145, 171-185, 256-257; Doumerc, "L'immigration dalmate à Venise," 328-333; Philippe Braunstein, “Cannaregio, zona di transito?," in La città italiana e i luoghi degli stranieri. XIV-XVIII secolo, ed. Donatella Calabi and Paola Lanaro (Roma, Bari: Laterza, 1998), 52-56; David Jacoby, “I greci e altre comunità tra Venezia e Oltremare," in I greci a Venezia, Atti del convegno internazionale di studio (Venezia, 5-7 novembre 1998), ed. Maria Francesca Tiepolo and Eurigio Tonetti (Venezia: Istituto Veneto di Scienze, Lettere ed Arti, 2002), 51-59, 66-67; Čralić, U gradu Svetog Marka, 122-170; Ivetic, "I Croati a Venezia," 19-20; Lucia Nadin, Migrazioni e integrazione. Il caso degli albanesi a Venezia (Roma: Bulzoni, 2008), 105-107, 123-124; Zannini, Venezia città aperta, 59-63, 151; Orlando, Migrazioni mediterranee, 176-178.

${ }^{6}$ Orlando, Migrazioni mediterranee, 116-117, 178-180.
} 
like conditions. Their legal status distinguished them from slaves only because their status of slavery was temporary and only lasted a few years ${ }^{7}$.

From 1386 onwards, the Venetian commune adopted a legal expedient to support such traffic and avoid canonical sanctions (and the anger of the Church) which banned the reduction in slavery of baptised Christians, at the same time regulating a clandestine market that had already grown up in a substantial and consistent manner. Indeed, in November of that year, the Senate, with a windowdressing measure, had condemned any form of forced recruitment of young people from the Balkan coasts, «que leviter vendite sunt et vendi possent et tractari pro sclavis, quod esset pessime factum et contra Deum et honorem nostri dominii (who are easily sold or can be sold and treated as slaves, something which would be terrible and against the will of God and the honour of our lordship)», granting them immediate freedom once they arrived in Venice. In order to eliminate all forms of violation of the prohibition, illegal sales were also outlawed with heavy penalties (fine of 100 lire and six months in prison), as it was «contra Deum et omnem equitatem (against God and any justice)», and the export of anime from Venice was strictly ban. At the same time, however, as a subtle means of getting around this impediment, the Venetian Council established, for all those unable to sustain the cost of the journey - in this case most, if not all of them, due to their young age and their povertystricken conditions - the possibility of paying transfer (set at three ducats for minors of ten-year-olds and six for adults) by providing four-years free service as domestic servants in the families who requested them. Needless to say, their work would have been carried out under conditions of substantial enslavement, thereby legalising forms of semi-slavery or time-limited servitude of baptised youngsters which was otherwise completely banned ${ }^{8}$.

In the face of an increased demand for domestic servants, a subsequent resolution from the Senate, issued in May 1388, reiterated the legitimacy of trafficking in individuals when carried out in compliance with the restrictions and arrangements set out a couple of years previously, raising the coercive period of servitude, to cover transfer costs (now brought to eight ducats) to ten years. On this occasion, the arguments put forward in favor of this measure were numerous, not only based on economic considerations - the need to avoid damaging a thriving market with excessively harsh and

\footnotetext{
${ }^{7}$ Vittorio Lazari, "Del traffico e delle condizioni degli schiavi in Venezia nei tempi di mezzo," in Miscellanea di Storia Italiana edita per cura della Regia Deputazione di Storia Patria, I (Torino: Fratelli Bocca, 1862), 489490; Alberto Tenenti, "Gli schiavi di Venezia alla fine del Cinquecento," Rivista Storica Italiana 67 (1955): 52 53; Charles Verlinden, L'esclavage dans l'Europe médiévale, II (Gand: Rijksuniversitat te Gent, 1977), 674-682, 685; Heers, Esclaves et domestiques au Moyen Âge, 153-155; Imhaus, Le minoranze orientali a Venezia, 63-64; Ducellier et al., Les chemins de l'exile, 146-147; Ducellier, "Albanais dans les Balkans et en Italie," 255; Doumerc, "L'immigration dalmate à Venise," 329-330; Romano, Housecraft and Statecraft, 47-49; Jacoby, "I greci e altre comunità," 65-66; Zannini, Venezia città aperta, 57-58; Orlando, Migrazioni mediterranee, 113. ${ }^{8}$ Archivio di Stato di Venezia (= Asve), Signori di notte al civil, b. 1 bis, “A. Capitolare primo", cc. $25 r-v$ (from a resolution of the Senate, issued in November 22, 1386).
} 
intransigent measures - but also on cultural and sociological ones. It was impossible to deny that those young individuals were structurally and even anthropologically different, and that a considerable amount of time was required to domesticate them: they were simple people, «rustice et rudis intellectus (rustic people and of low intellect)», and only an adequate period of enslavement could have refined them to the point that they could conveniently be introduced into the Venetian society. Instead, with the current law at that time, which limited their period of captivity to only four years, it was unlikely that any benefit could be gained, and one would be forced to free them precisely «quando esset tempus possendi aliquod comodum ex eis haberi (when some benefit could be obtained from them)». Moreover, it was equally indisputable and a consolation to the more fundamentalist consciences, that a temporary period of slavery among Christians would be preferable to perpetual slavery in the hands of the Turks, whose rule these individuals could fall under without the round-ups carried out along the Balkan coastline by Venetian traffickers?

\section{Social structures of reception and integration}

In essence, throughout the Middle Ages and within the Mediterranean macrocosm, Venice had maintained an essential role of impulse and of demographic catalyzation as well as economic and commercial, specific to its role as capital of a maritime empire on the one hand and world metropolis on the other. So, like every other city in the Ancien Régime, Venice was also interested in promoting the inclusion and integration of the migrant population that every year poured into the lagoon. The main reasons were financial, due to the functionality and importance of immigrant work compared to the city's production needs: as already said, the economy was the leading factor in attracting people to the lagoon, while simultaneously representing the fastest means of assimilation. The stable settlement of migrants, however, was also dictated by political needs; public well-being was at stake as well as security and social peace, and the aim of achieving a harmonious society, however complex and multicultural, like the Venetian one.

In particular, it was the official and legally approved aggregation structures, such as national confraternities (or schools), churches, hospitals or fondaci that especially favored and addressed the processes of migrant integration into the social and productive fabric of the city. In this respect, Venice had adopted a policy of consolidation and institutionalisation of ethnic-based and origin-based groups, legally recognised as autonomous national 'schools' and endowed with extensive self-rule. The first foreigners to obtain such a prerogative were those from Lucca, in 1359 (established in a brotherhood called Volto Santo), followed by those from Milan in 1361 (scuola di San Giovanni Battista e Sant'Ambrogio), the Florentines in 1435 (company of San Giovanni Battista), the Albanians in 1448 (scuola di San Gallo), the Dalmatians or Schiavoni in 1451 (scuola di San Giorgio e Trifone) and lastly the Greeks in 1498 (scuola di San Nicolo), while the Germans preferred the formation of

\footnotetext{
${ }^{9}$ ASVe, Senato, Deliberazioni, Misti, reg. 40, c. $120 v$ (May 21, 1388).
} 
various craft schools, albeit always on a national basis. This way, these groups, which were initially spontaneous and informal, were recognised as specific subjects, complete with autonomy and legal responsibility, with their own statutes, finances and their own administrative and internal management structure. For the Venetian commune, this meant the promotion of social policies of integration and assimilation of foreigners at zero-cost, without being directly involved; furthermore, the schools had established widespread control over the foreign presence in the city, exercised via mediation by the associations themselves. On the other hand, these national confraternities represented an opportunity for foreigners to bargain with the majority and governing group on the terms and modalities of their inclusion in the urban context, setting themselves up as pressure groups capable of influencing government choices, at the same time being themselves considerably influenced. For both of them, the schools had set up a point for meeting and dialogue, capable of limiting civic conflicts linked to the integration of foreign people and cultures into the urban environment and reducing hostility (instinctively) generated by ethnic and religious diversity ${ }^{10}$.

Not surprisingly, the key point of coordination in the city for the Dalmatians and Slavs had been the national confraternity, the Scuola dei Dalmati (or Scuola di San Giorgio e Trifone degli Schiavoni), officially established in 1451 , which had acted as a community gathering point and as a center for orientation and primary assistance to newcomers. Indeed, from 1426 onwards, they had obtained a chapel in the church of San Giovanni del Tempio, under the jurisdiction of the Cavalieri di San Giovanni di Gerusalemme, to gather informally and officiate in their own language. Only on May 19,1451 , however, the school was legally recognised; on that date, the Council of Ten authorised the foundation of the association, entitled to Santi Giorgio e Trifone (both protectors of the Dalmatian homeland), located in the same church of San Giovanni. The congregation was also allowed to celebrate liturgical functions and divine offices in Slavic language (the Dalmatian dialect, with strong Latin and Venetian contaminations). Just a few days after obtaining government permission, the Prior of the Cavalieri dell'Ordine di Malta had given the school a space adjacent to the Church of San

${ }^{10}$ Dennis Romano, Patrizi e popolani. La società veneziana nel Trecento (Bologna: Il Mulino, 1993), 19; Imhaus, Le minoranze orientali a Venezia, 285-287; Ducellier et al., Les chemins de l'exile, 219-220; Francesca Ortalli, Per salute delle anime e delli corpi. Scuole piccole a Venezia nel tardo Medioevo (Venezia: Marsilio, 2001), 104-110; Ducellier, “Albanais dans les Balkans et en Italie,” 261; Benjamin J. Kaplan, Divided by Faith. Religious Conflict and the Practice of Toleration in Early Modern Europe (Cambridge, Mass.: Belknap press of Harvard University press, 2007), 246; Giacomo Todeschini, Visibilmente crudeli. Malviventi, persone sospette e gente qualunque dal Medioevo all'età moderna (Bologna: Il Mulino, 2007), 264, 276-277; Zannini, Venezia città aperta, 24, 43, 60-61; Ravid, "Venice and its minorities," 452, 456-457; Orlando, Migrazioni mediterranee, 163169; Matteo Ceriana and Reinhold C. Mueller, "Radicamento delle comunità straniere a Venezia nel medioevo: 'scuole' di devozione nella storia e nell'arte," in Cittadinanza e mestieri. Radicamento urbano e integrazione nelle città bassomedievali (secc. XIII-XVI), Atti del convegno, ed. Beatrice Del Bo (Roma: Viella, 2014), 299331. 
Giorgio del Tempio, where the brothers (confratelli) could build a chapel and an altar dedicated to the two saints. They also obtained land within the hospice of Santa Caterina to build suitable housing for the association. At the start of the Sixteenth century, the site was then transferred to the building where is now, near Ponte della Commenda, a short distance from the Riva degli Schiavoni ${ }^{11}$.

Like other national schools, even the Dalmatian confraternity immediately carried out devotional and service functions, acting as a community aggregation pole and as a center for support, guidance and first aid to newcomers. In addition, as a legally recognised mediation institute, the school had set up essential channels for dialogue and negotiation between the commune and the minority group, favoring the instances of management and control of the institutions, on the one hand, and the dynamics concerning the integration of a foreign community on the other. Once incorporated into the city's service structures, it contributed to the dialectical exchanges between the various interlocutors, placing pressure on governing bodies, promoting the natio in the eyes of the local community, and conditioning the behavior of its affiliates, while still maintaining a strong identity and sense of belonging ${ }^{12}$.

Up until 1506, access to the school was limited only to Schiavoni; up until that point, inscription had been limited to those from the natio. The absolute ban, however, on the enrolment of Albanians, established by statute in 1445, remained in place even after 1506 (just as in the same statute, it was forbidden for Dalmatians to enroll in the Albanian school). Not even then, however, was removed the limitation, contained itself in the school statute, that only members of the natio could govern the association, leaving the election to the functions of gastaldo and vicario open exclusively to Dalmatians ${ }^{13}$.

In short, the confraternity carried out multiple functions. Firstly, it offered emotional support and social and health assistance to its migrants, acting as both a material and spiritual facility, and providing a welcome and security for the Schiavoni who had settled in the lagoon. Secondly, it provided information and advice, interwove relationships and established contacts and opportunities, providing migrants with the necessary knowledge on how to navigate through public facilities and citizens offices, or how to get a house, approach the job market, or start a family. In this sense, the school acted as a genuine gateway to society and its production structures; furthermore, it guaranteed its affiliates a minimum amount of economic and financial assistance, acting, in part, as a deposit bank

${ }^{11}$ Imhaus, Le minoranze orientali a Venezia, 279-280; Doumerc, "L'immigration dalmate à Venise," 327; Ducellier et al., Les chemins de l'exile, 208-212; Ortalli, Per salute delle anime e delli corpi, 103; Čoralić, $U$ gradu Svetog Marka, 215-262; Ivetic, "I Croati a Venezia," 21-22; Zannini, Venezia città aperta, 62-64; Orlando, Migrazioni mediterranee, 81-82; Ceriana, Mueller, "Radicamento delle comunità straniere a Venezia," 305-308.

${ }^{12}$ Orlando, Migrazioni mediterranee, 78-79.

${ }^{13}$ Imhaus, Le minoranze orientali a Venezia, 279-280, 285; Ortalli, Per salute delle anime e delli corpi, 103-104, 107; Zannini, Venezia città aperta, 62-64; Orlando, Migrazioni mediterranee, 82. 
for small savings and a financing bank and as a support institution in creating dowries for young girls in need. Lastly, it operated forms of internal supervision and control on any deviancy, with immediate returns in terms of public order and safety. On these grounds, therefore, it is not surprising the favourable attitude - albeit always very watchful and pragmatic - held by the Venetian 'state' towards the Scuola dei Dalmati and other national associations: for their ability to deal with foreigners, partially relieving government bodies of the need to manage and control them, which would have been much more expensive and difficult ${ }^{14}$.

\section{Coexistence and tolerance}

Foreigners in the city were, therefore, an ancient, functional and widespread presence, so much a part of its associative mechanisms and its production structures as to be a key and essential element. As we have seen, the city had made room for the minority groups and provided them sufficient scope for action and autonomy, even within a strict disciplinary context and one of accentuated integration. The objective remained that of peaceful coexistence and rapid integration, especially in economic terms, of the minorities into society; through complex interaction and negotiating practices, and very pragmatic and flexible processes of sharing common norms, symbols and values that would facilitate social cohesion.

Overall, these policies were, in essence, dictated by needs of opportunity and convenience; it was in the interest of Venice's government, for reasons of social stability and economic productivity, to guarantee the coexistence within the city of different ethnic and religious communities in close proximity, without resorting to force or violence. Venice had shown a pragmatic and interested concern, almost opportunistic; to ensure the coexistence of different groups, the city had (necessarily) assumed an open approach and one of dialogue with minorities in order to neutralise any excesses and imbalances caused by diversity, and encourage the assimilation of differences.

The local Venetian community had looked upon the minorities with a mixture of discomfort and practical tolerance. Its experience as a maritime and trade city, always open to exchanges and communication, had developed in people an innate ability to compare with and accept diversity, and developed a language, made of negotiation and arrangement, able of favoring the integration of migrant populations. In such a context, tolerance had assumed a concrete, almost physical and material dimension, becoming a social practice rather than an abstract concept or a political attitude; a form of

\footnotetext{
${ }^{14}$ Ducellier, "Les Albanais à Venise," 419; Imhaus, Le minoranze orientali a Venezia, 278-279, 286-287, 380, 419; Ducellier et al., Les chemins de l'exile, 208-220; Lorenz Böninger, "Quant’è bello e gioioso vivere insieme. La regula della Scuola dei calzolai tedeschi a Venezia (1383)," in La "regula" bilingue della Scuola dei calzolai tedeschi a Venezia del 1383, ed. Lorenz Böninger, con studio linguistico di Maria Giovanna Arcamone (Venezia: Il comitato editore, 2002), VII-IX, XV, XXI; Ortalli, Per salute delle anime e delli corpi, 102-104, 108-109; Nadin, Migrazioni e integrazione, 45-46, 102; Zannini, Venezia città aperta, 60-61; Orlando, Migrazioni mediterranee, 168-169.
} 
behavior instinctively capable of fostering interaction between people of different languages, culture and religion and facilitating their coexistence under conditions of close proximity. The city was crossed by a dense network of constant and daily interactions between leading and minority groups; no matter what language people spoke or what culture or faith they belonged to, they frequented one another, had economic and social relations and were bound by common interests; the closeness of their relationships had made them familiar with each other, irrespective of how they communicated, their way of dressing or behaving, their cultural references, or to whom or how they prayed. The proximity and sharing of physical, social and common spaces encouraged exchange between the city and the foreign communities, while in the continuous search for tireless synthesis between the dynamics of one's own identity and adhesion to common languages to ensure coexistence ${ }^{15}$.

Social proximity and the sharing of space also produced a strong demand for communication and reciprocal consciousness between the various national groups in the city. Coexistence had fueled the need for dialogue between the peoples and the sharing of their respective languages, traditions, laws and knowledge; reciprocal awareness had facilitated the spread of cultures of each other on both sides, contributing greatly to establishing a more flexible and articulated identity and to understanding of the surrounding world. Communication ran along the tracks of a daily life made up of stable and recurring relationships: common patronage; spaces for trade and economy; moments of enjoyment and recreation; repeated opportunities for meeting and socialising; mixed marriages. Essential and almost obligatory continuous interaction between different people and worlds had thus generated a means to accentuate ethnic mixing, permitting the development of complex cultures, the result of interwoven and meticulous knowledge, and the coexistence of different nationes ${ }^{16}$.

Obviously, coexistence with foreigners had not excluded hardships and difficulties in any way. Even once it was achieved, this equilibrium always remained unstable and precarious, marked by recurring unease and conflicts, inbred into a multi-ethnic and pluralistic society like Venice. The result had been an intense relationship with minorities, but always very complicated, at the same time infused with vexation and curiosity, repulsion and attraction. Especially in times of economic downturn or demographic saturation, the foreigner would often once again pose a threat to the majority, an obstacle to its social and economic progress and a challenge to its cultural integrity and security. Diversity, therefore, had once again become a reason for fear and an opportunity to push minority groups to the margins and increase controls carried out on them as well as implementing segregation ${ }^{17}$.

\footnotetext{
${ }^{15}$ Kaplan, Divided by Faith, 8-9, 239-245; Orlando, Migrazioni mediterranee, 383-385.

${ }^{16}$ Cecilie Hollberg, Deutsche in Venedig im späten Mittelalter. Eine Untersuchung von Testamenten aus dem 15. Jahrhundert (Göttingen: V \& R, 2005), 247-251; Zannini, Venezia città aperta, 94; Ravid, "Venice and its minorities," 483-484; Orlando, Migrazioni mediterranee, 385-386.

${ }^{17}$ Kaplan, Divided by Faith, 9-19; Orlando, Migrazioni mediterranee, 386-387.
} 
Sources, for example, reveal a widespread alarm linked to crimes committed by foreigners; in fact, where it was possible to assess, migrant crime rates were highly significant and sometimes higher than those of natives, especially in certain categories of crimes, often with higher visibility and those more feared and deplored by locals. According to data from scholars on this subject, more than $30 \%$ of the offenses for fighting and injury, in the period from 1350 to 1460 , were committed by foreigners; similar percentages were found in the case of murders; in the case of theft, the delinquency rate for foreigners reached levels greater than $50 \%$ (but studies here are related only to the Fourteenth century), with the Slavs dominating all other minorities ${ }^{18}$.

The data undoubtedly reveals a clear unease: certain extraneity and social marginality of foreigners turned, almost instinctively, into widespread delinquency and crime, spreading a feeling of uncertainty and fear among the majority population and raising the threshold of attention from the public authorities. The commune's initial reaction was to tighten up on the penalties imposed on foreigners; the condition of a foreigner, an immigrant or a vagabond had become, in this case, an aggravating circumstance, capable of automatically making the sentence handed down more severe. It would, however, be hazardous to overemphasize the crime rates found among foreigners and automatically associate them with levels of poor integration of the minorities in the city; despite the alarm and concern raised by foreign delinquency, immigrants and minorities had never become a social problem in Venice nor had local authorities ever been forced to adopt special jurisdiction for foreigners, with the exception of the discriminant of more severe punishments against them compared to those given to natives ${ }^{19}$.

On hindsight, the offenses were largely committed by isolated, marginalised individuals; they were the «puoveri (poors)» that the city had been unable to assimilate, completely disconnected from the networks of urban relations and social networks and deprived of its economic and associative resources. Many were homeless, unemployed vagabonds, who often came to the city for criminal purposes or who were forced into a life of crime for to survive; their criminal behavior was often determined by contingent and circumstantial factors, linked to their own inability to access the resources made available by society, thereby being excluded from places of production and use of the

\footnotetext{
${ }^{18}$ Stanley Chojnacki, "Crime, punishment and the Trecento Venetian State," in Violence and civil disorder in Italian cities, 1200-1500, ed. Lauro Martines (Berkeley, Los Angeles, London: University of California press, 1972), 184-228; Stefano Piasentini, Alla luce della luna. I furti a Venezia, 1270-1403 (Venezia: Il cardo, 1992), 95-104; Imhaus, Le minoranze orientali a Venezia, 333-358; Orlando, Migrazioni mediterranee, 494-496.

${ }^{19}$ Ducellier et al., Les chemins de l'exile, 193-201; Piasentini, Alla luce della luna, 95-97; Luca Molà and Reinhold C. Mueller, "Essere straniero a Venezia nel tardo Medioevo: accoglienza e rifiuto nei privilegi di cittadinanza e nelle sentenze criminali," in Le migrazioni in Europa, 839-840; Imhaus, Le minoranze orientali a Venezia, 333-336, 350-358, 390; Zannini, Venezia città aperta, 78-79; Orlando, Migrazioni mediterranee, 495496.
} 
immigrants share capital (parental and ethnic networks, neighborhood and professional networks, national schools and so on $)^{20}$.

\section{Mixed marriages}

In this context, integration had certain obligatory steps: an accommodation, a job and the formation of a family. In particular, marriage served as a primary space for solidarity and interaction, reinforcing the social position of the migrant and guaranteeing him/her the bare essentials in security and the indispensable support in the city's allocation processes and in the insertion dynamics into its production mechanisms. It was no coincidence that, once in the city, many migratory experiences ended in marriage. Indeed, most of the migrants were young and single on arrival in the lagoon and naturally inclined to create a family to give stability and continuity to their plans. There is no doubt, therefore, about the importance of marriages within migratory processes, such as the integration and putting down roots of new arrivals in the host society. In particular, mixed marriage, whether interethnic or inter-confessional, had been one of the most important factors for newcomers of integration in their receiving society, simultaneously promoting spaces of interaction between the groups and meeting areas between cultural models and different regulations, with inevitable outcomes not only on a social but also on a legal and cultural level. Mixed marriage led to the break-up of the good endogamous marriage axiom, performed within minority groups, to keep its peculiarities and cultural diversity intact. In this way, the margins for communication between the various ethnic and religious groups became more dynamic and sensitive (but also slippery and conflicting), with inevitable consequences on integration and subsequent acculturation processes. The heterogamous marriage also produced a widening of the marriage market, which was essential in the case of migrations made up mostly of single males, mostly unmarried at the time of their transfer ${ }^{21}$.

Not surprisingly, the rate of exogamy remains, even today, one of the key indicators in calculating the degree of integration achieved by migrant populations and the quality of their inclusion $^{22}$. Some of the data in our possession, mostly deduced from a source in the last few years of growing interest and attention among the scholars, such as the marriage trials kept in the ecclesiastical archives, are from this point of view highly significant: up until the Council of Trent (1563), marriages that included foreigners were exogamic in $74 \%$ of cases, while only the remaining $26 \%$ of cases involve endogamous marriages, id est contracted between men and women of the same ethnic and linguistic background. The disarticulation of the data at a level of individual national groups reveals

\footnotetext{
${ }^{20}$ Ducellier, "Les Albanais à Venise," 408-409; Philippe Braunstein, "Remarques sur la population allemande de Venise à la fin du moyen âge," in Venezia centro di mediazione fra Oriente e Occidente, 237; Piasentini, Alla luce della luna, 97-103; Zannini, Venezia città aperta, 77-78; Orlando, Migrazioni mediterranee, 496-497.

${ }^{21}$ Orlando, Migrazioni mediterranee, 183-189, 343-344.

${ }^{22}$ Ducellier et al., Les chemins de l'exile, 351-353; Imhaus, Le minoranze orientali a Venezia, 323-325; Kaplan, Divided by Faith, 267-268.
} 
only slight fluctuations compared to the overall framework. In the case of the Greeks, the rate of exogamy rises to $79 \%$; it drops slightly for the Germans and Albanians respectively to 73 and $72 \%$; then drops most significantly in the case of the Schiavoni from 74 to $62 \%$. Moreover, the source seems to photograph completely the pluralistic dimension of the Venetian people and the percentage of foreigners in the city. Wholly in line with the evaluations made at the beginning, more than one-third of the cases dealt with in the ecclesiastical court in the period from 1385 to 1563 concerned marriages between or with foreigners, with averages usually higher than $30 \%$ and peaking at $47 \%$ in the fifteenth century, the period most affected by immigration from the Balkan Peninsula ${ }^{23}$.

The reasons behind such widespread and persistent exogamic behavior can easily be explained. If homogamy was motivated, even subconsciously, by obvious reasons of cultural and linguistic affinity and the desire to preserve proper cultural and religious identities, thus maintaining the communicative and symbolic codes of the minority group, heterogamy, while questioning the most secure and immediate references (those of one's community of origin), nonetheless made easier dialogue and sharing with the culture, language and traditions of the other groups in the city, starting with the native-majority group. Still more persuasive, however, were social and economic reasons. Firstly, because, as already mentioned, a mixed marriage was one of the simplest routes to integration in the receiving society and the best possible means of ensuring social protection and interaction with its associative and productive structures. Secondly, for logistical reasons, linked to the very configuration of the marital market of foreigners, inevitably focused on choices outside one's reference group, especially for first-generation immigrants, given the prevalence of male migration flows. Lastly, because heterogamy, freeing the foreigners of their, sometimes overly cumbersome, burden of ethnic and linguistic constraints, amplified their prospects of understanding with the host community and relationship with its support and assistance organisations, thus obtaining a house and job more easily (at the root of every process of inclusion in the majority group) ${ }^{24}$.

As mentioned, the disjointed data shows a decline in exogamy rates relatively to the Dalmatian-Slavic community (from 74 to $62 \%$ ). These figures show a stronger inclination of the

\footnotetext{
${ }^{23}$ The matrimonial causes kept in the Archivio storico del patriarcato di Venezia, in the archive of the patriarcal Curia, Sezione antica, in the series Actorum, Mandatorum, Praeceptorum, Causarum Matrimonioroum, Filciae Causarum and Sententiarum, in the period from 1385 to 1563 (closing date of the Council of Trent), concern for $28 \%-672$ out of 2,388 analysed processes - marriages between or with foreigners. Of these, 499 causes out of 672 are related to exogamous marriages, while 173 out of 672 concern endogamous marriages. The legitimate doubts on the reliability of the source - considering the nature of the documentation, related to matrimonial conflicts, the high rate of exogamous marriages could be more simply motivated by their greater fragility than endogamous ones - are removed by the results of recent researches based on notarial documents, which have shown, relatively to the Dalmatian-Slavic community settled in Venice, rates of exogamy close to the figures provided by the judicial source: see Čoralić, U gradu Svetog Marka, 172-173; Ivetic, "I Croati a Venezia," 21.

${ }^{24}$ Orlando, Migrazioni mediterranee, 345-346.
} 
Dalmatians and Slavs - without, however, affecting the mainly heterogamous structure of the group towards homogamic unions, which certainly offered more guarantees to immigrants both in terms of sharing cultural and linguistic continuity, as well as family stability. It is most likely, even only for reasons of proximity and ease of communication between the Istrian-Dalmatian coast and the Venetian lagoon, that the Slavic marriage market was fed by a more steady and consistent female immigration than from other foreign minorities, making marriage choices within the group to which one belonged more likely, even for first generations. Overall, however, even when the data is disaggregated, it fully confirms the willingness, if not the need, of foreigners to form mixed couples and integrate themselves into the local population as soon as possible. As for the possible combinations, the prevailing trend, in the case of exogamic marriages, was of course to marry a native, for the obvious advantages this brought in terms of assimilation into the majority group and familiarisation with its social and economic structures - in $65 \%$ of cases for the Slavs, $58 \%$ for the Greeks, $54 \%$ for Albanians and $44 \%$ for the Germans -, starting with the acquisition of Venetian citizenship, granted from 1407 onwards to any foreigner who married a Venetian woman ${ }^{25}$.

In other words, mobility, in a city with high immigration like Venice, had multiplied the opportunities to form heterogamous marriages; for their part, mixed unions favored and supported the opportunities for newcomers to integrate into the host society, acting as a tool for order and control of the disadvantages arising from demographic instability. Essentially, exogamy was one of the most effective means in Venice of establishing social relations and accelerating the integration processes for foreigners in the urban environment, facilitating the dynamics of interaction and coexistence between minorities and the majority group ${ }^{26}$.

\section{Conclusions}

In conclusion, throughout the Middle Ages, Venice had maintained its physiognomy as a multi-ethnic and multicultural city, made up of multiple coexistences, regular (and necessary) transfers of people from different backgrounds, cultures and faiths and a daily (and equally necessary) dialogue between different groups and religions. In other words, it was a Mediterranean metropolis closely and deeply affected by human mobility and an environment constantly struggling with complex interactions and ethnic, cultural and religious combinations: a city that has become, by need and almost in spite of himself, a multi-communitarian society; yet a place capable of transforming differences into dialogue and diversity into an opportunity for comparison and fusion, becoming the sincretic and multi-ethnic city that I have briefly attempted to describe here.

\footnotetext{
${ }^{25}$ Orlando, Migrazioni mediterranee, 346-347.

${ }^{26}$ Orlando, Migrazioni mediterranee, 348-356, 369-372.
} 
Bibliography

Beloch, Julius Karl, "La popolazione di Venezia nei secoli XVI e XVII.” Nuovo Archivio Veneto n.s., II, no. 3-I (1902): 5-14.

Böninger, Lorenz, "Quant'è bello e gioioso vivere insieme. La regula della Scuola dei calzolai tedeschi a Venezia (1383)." In La "regula” bilingue della Scuola dei calzolai tedeschi a Venezia del 1383, edited by Lorenz Böninger, con studio linguistico di Maria Giovanna Arcamone, V-XXV. Venezia: Il comitato editore, 2002.

Braunstein, Philippe, "Remarques sur la population allemande de Venise à la fin du moyen âge." In Venezia centro di mediazione fra Oriente e Occidente (secoli XV-XVI). Aspetti e problemi, Atti del II convegno internazionale di storia della civiltà veneziana, Venezia 3-6 ottobre 1973, I, edited by Hans-Georg Beck, Manousos Manoussacas, and Agostino Pertusi, 233-243. Firenze: Olschki, 1977.

Braunstein, Philippe, “Cannaregio, zona di transito?.” In La città italiana e i luoghi degli stranieri. XIV-XVIII secolo, edited by Donatella Calabi and Paola Lanaro, 52-62. Roma, Bari: Laterza, 1998.

Braunstein, Philippe, Les Allemands a Venise, 1380-1520. Rome: Ecole française de Rome, 2016.

Ceriana, Matteo and Reinhold C. Mueller, "Radicamento delle comunità straniere a Venezia nel medioevo: 'scuole' di devozione nella storia e nell'arte." In Cittadinanza e mestieri. Radicamento urbano e integrazione nelle città bassomedievali (secc. XIII-XVI), Atti del convegno, edited by Beatrice Del Bo, 299-331. Roma: Viella, 2014.

Chojnacki, Stanley, "Crime, punishment and the Trecento Venetian State." In Violence and civil disorder in Italian cities, 1200-1500, edited by Lauro Martines, 184-228. Berkeley, Los Angeles, London: University of California press, 1972.

Čoralić, Lovorka, U gradu Svetog Marka. Povijest hrvatske zajednice u Mlecima. Zagreb: Golden marketing, 2001.

Doumerc, Bernard, "L’immigration dalmate à Venise à la fin du Moyen-Age.” In Le migrazioni in Europa. Secc. XIII-XVIII, Atti della “Venticinquesima Settimana di Studi”, Istituto Internazionale di Storia economica " $F$. Datini”, Prato, edited by Simonetta Cavaciocchi, 325-333. Firenze: Le Monnier, 1994.

Ducellier, Alain, "Les Albanais à Venise aux XIV et $\mathrm{XV}^{\mathrm{e}}$ siècles." Centre de recherches d'histoire et civilisation byzantines. Travaux et mémoires 2 (1967): 405-420.

Ducellier, Alain, “Albanais dans les Balkans et en Italie à la fin du Moyen Age: courants migratoires et connivences socio-culturelles." In Le migrazioni in Europa. Secc. XIII-XVIII, Atti della "Venticinquesima Settimana di Studi”, Istituto Internazionale di Storia economica “F. Datini”, Prato, edited by Simonetta Cavaciocchi, 233-269. Firenze: Le Monnier, 1994.

Alain Ducellier, Bernard Doumerc, Brunehilde Imhaus, and Jean de Miceli, Les chemins de l'exile. Bouleversements de l'Est Européen et migration vers l'Ouest à la fin du Moyen Âge. Paris: A. Colin, 1992.

Fedalto, Giorgio, "Le minoranze straniere a Venezia tra politica e legislazione.” In Venezia centro di mediazione fra Oriente e Occidente (secoli XV-XVI). Aspetti e problemi, Atti del II convegno internazionale di storia della civiltà veneziana, Venezia 3-6 ottobre 1973, I, edited by Hans-Georg Beck, Manousos Manoussacas, and Agostino Pertusi, 143-162. Firenze: Olschki, 1977.

Gestrin, Ferdo, “Migracije iz Dalmacije v Italijo v 15 in 16 stoletin.” Zgodovinski caposi 30 (1976): 269-276. 
Heers, Jacques, Esclaves et domestiques au Moyen Âge dans le monde méditerranéen. Paris: Fayard, 1981.

Hollberg, Cecilie, Deutsche in Venedig im späten Mittelalter. Eine Untersuchung von Testamenten aus dem 15. Jahrhundert. Göttingen: V \& R, 2005.

Imhaus, Brunehilde, Le minoranze orientali a Venezia. 1300-1510. Roma: Il Veltro, 1997.

Ivetic, Egidio, "I Croati a Venezia. Alcuni studi recenti." Studi veneziani 46 (2003): 15-30.

Jacoby, David, "I greci e altre comunità tra Venezia e Oltremare." In I greci a Venezia, Atti del convegno internazionale di studio (Venezia, 5-7 novembre 1998), edited by Maria Francesca Tiepolo and Eurigio Tonetti, 41-82. Venezia: Istituto Veneto di Scienze, Lettere ed Arti, 2002.

Kaplan, Benjamin J., Divided by Faith. Religious Conflict and the Practice of Toleration in Early Modern Europe. Cambridge, Mass.: Belknap press of Harvard University press, 2007.

Lazari, Vittorio, "Del traffico e delle condizioni degli schiavi in Venezia nei tempi di mezzo." In Miscellanea di Storia Italiana edita per cura della Regia Deputazione di Storia Patria, I, 463-501. Torino: Fratelli Bocca, 1862.

McKee, Sally, "Domestic Slavery in Renaissance Italy." Slavery \& Abolition 29, no. 3 (September 2008): 305326.

Molà, Luca and Reinhold C. Mueller, "Essere straniero a Venezia nel tardo Medioevo: accoglienza e rifiuto nei privilegi di cittadinanza e nelle sentenze criminali." In Le migrazioni in Europa. Secc. XIII-XVIII, Atti della "Venticinquesima Settimana di Studi", Istituto Internazionale di Storia economica "F. Datini”, Prato, edited by Simonetta Cavaciocchi, 839-851. Firenze: Le Monnier, 1994.

Mueller, Reinhold C., "Peste e demografia. Medioevo e Rinascimento." In Venezia e la peste. 1348/1797, 93-96. Venezia: Comune di Venezia, Assessorato alla cultura e belle arti, 1979.

Mueller, Reinhold C., Immigrazione e cittadinanza nella Venezia medievale. Roma: Viella, 2010.

Nadin, Lucia, Migrazioni e integrazione. Il caso degli albanesi a Venezia. Roma: Bulzoni, 2008.

Orlando, Ermanno, Migrazioni mediterranee. Migranti, minoranze e matrimoni a Venezia nel basso medioevo. Bologna: Il Mulino, 2014.

Ortalli, Francesca, Per salute delle anime e delli corpi. Scuole piccole a Venezia nel tardo Medioevo. Venezia: Marsilio, 2001.

Piasentini, Stefano, Alla luce della luna. I furti a Venezia, 1270-1403. Venezia: Il cardo, 1992.

Ravid, Benjamin, "Venice and its minorities." in A Companion to Venetian History, 1400-1797, edited by Eric R. Dursteler, 449-485. Leiden, Boston: Brill, 2013.

Romano, Dennis, Patrizi e popolani. La società veneziana nel Trecento. Bologna: Il Mulino, 1993.

Romano, Dennis, Housecraft and Statecraft. Domestic Service in Renaissance Venice, 1400-1600. Baltimore, London: The Johns Hopkins University Press, 1996.

Tenenti, Alberto, "Gli schiavi di Venezia alla fine del Cinquecento." Rivista Storica Italiana 67 (1955): 52-69.

Todeschini, Giacomo, Visibilmente crudeli. Malviventi, persone sospette e gente qualunque dal Medioevo all'età moderna. Bologna: Il Mulino, 2007.

Verlinden, Charles, L'esclavage dans l'Europe médiévale, II. Gand: Rijksuniversitat te Gent, 1977.

Zannini, Andrea, Venezia città aperta. Gli stranieri e la Serenissima, XIV-XVIII sec. Venezia: Marcianum press, 2009. 